\title{
Application of Rho Antagonist to Neuronal Cell Bodies Promotes Neurite Growth in Compartmented Cultures and Regeneration of Retinal Ganglion Cell Axons in the Optic Nerve of Adult Rats
}

\author{
Johanne Bertrand, ${ }^{1}$ Matthew J. Winton, ${ }^{1}$ Nieves Rodriguez-Hernandez, ${ }^{3}$ Robert B. Campenot, ${ }^{2}$ and Lisa McKerracher ${ }^{1,3}$ \\ ${ }^{1}$ Département de Pathologie et biologie cellulaire, Université de Montréal, Montréal, Québec, Canada, H3T 1J4, ${ }^{2}$ Department of Cell Biology, University of \\ Alberta, Edmonton, Alberta, Canada, T6G 2H7, and 3BioAxone Thérapeutique, Montréal, Québec, Canada, H2X 3P9
}

Inactivation of Rho promotes neurite growth on inhibitory substrates and axon regeneration in vivo. Here, we compared axon growth when neuronal cell bodies or injured axons were treated with a cell-permeable Rho antagonist (C3- 07) in vitro and in vivo. In neurons plated in compartmented cultures, application of C3-07 to either cell bodies or distal axons promoted axonal growth on myelinassociated glycoprotein substrates. In vivo, an injection of C3- 07 into the eye promoted regeneration of retinal ganglion cell (RGC) axons in the optic nerve after microcrush lesion. Delayed application of C3-07 promoted RGC growth across the lesion scar. Application of C3- 07 completely prevented RGC cell death for 1 week after axotomy. To investigate the mechanism by which Rho inactivation promotes RGC growth, we studied slow axonal transport. Reduction in slow transport of cytoskeletal proteins was observed after axotomy, but inactivation of Rho did not increase slow axonal transport rates. Together, our results indicate that application of a Rho antagonist at the cell body is neuroprotective and overcomes growth inhibition but does not fully prime RGCs for active growth.

Key words: axon regeneration; optic nerve injury; sympathetic neuron; compartmented culture; RGC survival; slow axonal transport

\section{Introduction}

CNS neurons fail to spontaneously regenerate their axons after injury partly because of growth inhibitors present in myelin and at the glial scar (McKerracher and Winton, 2002; David and Lacroix, 2003). Growth inhibitory proteins activate Rho GTPase, which leads to growth cone collapse and growth inhibition (Jalink et al., 1994; Tigyi et al., 1996; Jin and Strittmatter, 1997; Lehmann et al., 1999). In vitro, treatment with the Rho-specific antagonist C3-transferase inactivates Rho and stimulates neurite growth on inhibitory substrates (Dergham et al., 2002; Monnier et al., 2003). Cell-permeable versions of C3 have been used for more effective Rho inactivation (Winton et al., 2002; Shearer et al., 2003). From such studies, it is not known whether Rho antagonists act on the cell body or growth cone to promote neurite growth.

A simple paradigm to study CNS regeneration is the adult rat optic nerve lesion. Strategies to promote retinal ganglion cell (RGC) regeneration by blocking growth inhibition in vivo often

\footnotetext{
Received Sept. 22, 2004; revised Dec. 13, 2004; accepted Dec. 14, 2004.

We gratefully acknowledge the Canadian Institutes of Health Research (CIHR) for financial support. J.B. was supported by a CIHR scholarship. We thank Charles Essagian, Karen Lund, and Rozica Bolovan for technical assistance.

Correspondence should be addressed to L. McKerracher, Université de Montréal, Département de Pathologie et biologie cellulaire, 2900 Edouard Montpetit, Pavillon Roger-Gaudry, S-507 Montréal, Québec, Canada, H3T 1 J4. E-mail: lisa.mckerracher@bioaxone.com.

D01:10.1523/JNEUROSCI.3931-04.2005

Copyright $\odot 2005$ Society for Neuroscience $\quad$ 0270-6474/05/251113-09\$15.00/0
}

use local delivery techniques after optic nerve injury (Weibel et al., 1994; Lehmann et al., 1999). In contrast, treatments aimed at boosting axonal growth capacity are successful when acting on the cell body of RGCs (Berry et al., 1996; Leon et al., 2000; Cui et al., 2003; Yin et al., 2003; Fischer et al., 2004b; Monsul et al., 2004). The relationship between regenerative effects on cell bodies versus injured axons is not well understood.

RGCs die after optic nerve injury, and this must be taken into account when studying regeneration. In rats, transection of the optic nerve close to the eye causes a delayed RGC death, with cells beginning to die $\sim 4 \mathrm{~d}$ later. One week after injury, $\sim 50 \%$ of RGCs have died, and by 2 weeks, $<20 \%$ survive (Villegas-Perez et al., 1993; Mansour-Robaey et al., 1994).

We previously demonstrated that Rho antagonists applied to injured optic nerve promote regeneration of RGC axons (Lehmann et al., 1999). Here, we determine the effect of Rho antagonist application to cell bodies versus axons. For in vitro studies, we used compartmented cultures, a well-characterized cell culture system in which cell bodies and proximal axons of superior cervical ganglion neurons are located in a separate fluid compartment from their distal axons (Campenot, 1977; Campenot and Martin, 2001). In vivo, injection into the eye after microlesion of the optic nerve provides an ideal model to examine regeneration after specific treatment of the cell body. We show that Rho antagonists promote axonal growth on inhibitory substrates when applied to either cell bodies or distal axons. As well, our results show that Rho antagonists promote RGC regeneration when ap- 
plied to cell bodies, as previously observed when applied to injured axons (Lehmann et al., 1999), and that delayed treatments allow RGC axons to regenerate across the lesion scar. Intravitreal application of Rho antagonists also increased RGC survival. Despite its impact on RGC survival and regeneration, C3-07 does not boost slow axonal transport rates that decrease after axotomy.

\section{Materials and Methods}

Rho antagonists C3-05 and C3-07. C3-05 is a modified version of C3ADP-rybosyltransferase from Clostridium botulinum with an added transport sequence that facilitates entry into cells. C3-05 was prepared as described previously (Winton et al., 2002) by affinity purification and was $\sim 95 \%$ pure. During the course of our experiments, a newer version of C3-05 was made to increase purity and yield. C3-07 has the same enzymatic activity and transport sequence as C3-05, and its ability to inactivate Rho was verified by Rho pull-down assay, as described for C3-05 by Dubreuil et al. (2003) (data not shown). C3-07 differs from C3-05, because the DNA sequence for the GST tag used for affinity purification of C3-05 was removed before subcloning into a $\mathrm{pET}$ vector. C3-07 was purified by fast-protein liquid chromatography (FPLC), as described previously (Han et al., 2001), and activity was verified by neurite outgrowth assay, as for C3-05 (Winton et al., 2002). The FPLCpurified protein was $\sim 99 \%$ pure.

Axonal regrowth after axotomy in Campenot chambers. Superior cervical ganglion (SCG) from postnatal day 0 (P0) to P1 were dissociated and plated into compartmented cultures (Tyler Research, Edmonton, Alberta) as described previously (Campenot and Martin, 2001). Briefly, compartmented cultures were constructed in collagen-coated $35 \mathrm{~mm}$ culture dishes using a Teflon divider that separates the neurons into individual compartments (i.e., cell bodies and distal axons) (see Fig. $1 \mathrm{~A}$ ). The dish floor was patterned into 20 parallel collagen tracks bordered by scratches made with a specially constructed pin rake. To form the compartments, a Teflon divider was sealed to the dish floor with silicone grease. This sealing method was shown to prevent the exchange of media between the individual compartments (Campenot, 1977, 1979; MacInnis et al., 2003). Neurons were then plated in the center compartment and extended axons under the grease barrier into the two side compartments. The cells were maintained in L15CO2 medium supplemented with $2.5 \%$ rat serum, $20 \mathrm{ng} / \mathrm{ml} \mathrm{NGF}$ (Cedarlanes Laboratories, Hornby, Ontario), vitamin $\mathrm{C}$, and $10 \mu \mathrm{M}$ cytosine arabinside (Sigma, Oakville, Ontario). Distal axons were axotomized 5-7 d after plating by spraying cold, sterile water through a 0.22 gauge needle into the two side chambers. This process was repeated $\sim 3-4$ times, until all distal axons had been axotomized (Kimpinski et al., 1997; MacInnis et al., 2003). After axotomy, 2.5 $\mu \mathrm{g} / \mathrm{ml} \mathrm{C3-07} \mathrm{was} \mathrm{added} \mathrm{to} \mathrm{the} \mathrm{various} \mathrm{compartments} \mathrm{(i.e.,} \mathrm{cell} \mathrm{body}$ compartment only, distal axon compartments only, or all three compartments), and axonal growth into side chambers was measured $3 \mathrm{~d}$ after axotomy. The media was changed every $48 \mathrm{~h}$, and C3-07 was re-added to the fresh media in treated compartments. Axonal growth was measured from the grease barrier to the tip of the longest axon in a track. Measurements were made with an inverted microscope fitted with a digitizer that tracks stage movements to an accuracy of $\pm 5 \mu \mathrm{m}$ (Campenot and Martin, 2001). Experiments were completed in triplicate with a minimum of 10 tracks per culture chamber.

After axonal growth was measured and with the Teflon dividers still in place, the cultures were washed twice with cold Tris-buffered saline and lysed in modified radioimmunoprecipitation assay buffer [50 mM Tris, $\mathrm{pH} 7.2,1 \%$ Triton X-100, $0.5 \%$ sodium deoxycholate, $0.1 \%$ SDS, $500 \mathrm{~mm}$ $\mathrm{NaCl}, 10 \mathrm{~mm} \mathrm{MgCl}, 1 \mu \mathrm{g} / \mathrm{ml}$ leupeptin (Roche, Laval, Quebec), $1 \mu \mathrm{g} / \mathrm{ml}$ aprotinin (Roche), $1 \mathrm{~mm}$ phenylmethyl-sulfonyl fluoride (PMSF) (Sigma)]. Separate lysates from cell bodies/proximal axons and distal axon compartments were pooled across three cultures, clarified by centrifugation at $14,000 \times g$ for $10 \mathrm{~min}$ at $4^{\circ} \mathrm{C}$, and stored at $-80^{\circ} \mathrm{C}$. Proteins in the lysates were separated on $12 \%$ acrylamide gels and transferred to nitrocellulose. The membranes were blocked in 5\% powdered milk, incubated in blocking buffer with a polyclonal C3 antibody (1:4000) (Winton et al., 2002), and the immunoreactive bands revealed by HRP-based chemiluminescent reaction (Pierce, Rockford, IL). Protein levels were determined by protein assay and verified by Ponceau Red staining.

Axonal growth on myelin-associated glycoprotein in Campenot chambers. Myelin-associated glycoprotein (MAG)-coated dishes were prepared $1 \mathrm{~d}$ before use. MAG was purified as described previously (McKerracher et al., 1994) and applied to collagen-coated $35 \mathrm{~mm}$ dishes at $4 \mu \mathrm{g}$ of total protein per dish and allowed to dry overnight in a laminar flow hood. MAG was applied only in areas that would correspond to the side chambers of the compartmented culture. After the MAG substrate dried, the dishes were washed with water, the compartmented cultures were assembled, and dissociated SCG neurons were plated in the center compartments. After $1 \mathrm{~d}$ in culture, C3-07 $(2.5 \mu \mathrm{g} / \mathrm{ml})$ was added to either the cell body/proximal axon compartment only, the distal axon compartments only, or all three compartments, and axonal growth into the side compartments was measured for three consecutive days. The media was changed after $48 \mathrm{~h}$, at which time the $\mathrm{C} 3-07$ was replenished in the fresh media in treated compartments. Experiments were completed in triplicate with a minimum of 10 tracks measured per culture chamber.

Intraorbital microlesion surgery and C3-05/07 treatment. Intraorbital microlesions effectively axotomize all RGC axons and provide a welldefined lesion site (Selles-Navarro et al., 2001). Microlesions were performed on female Sprague Dawley rats (180-200 g; Charles River, StConstant, Québec, Canada) under gas anesthesia with 2.5-3\% isoflurane in oxygen. The left optic nerve was exposed, the dural sheath was slit longitudinally, and the nerve was crushed $1 \mathrm{~mm}$ from the globe by holding a tight knot made with a $10-0$ suture for $60 \mathrm{~s}$. The suture was then completely removed. Treated animals were injected intravitreally with 10 $\mu \mathrm{g}$ of $\mathrm{C} 3-05$ or $1 \mu \mathrm{g}$ of C3-07 in $5 \mu \mathrm{l}$ of PBS immediately after the microlesion or $4 \mathrm{~d}$ later. Control animals were injected with $5 \mu \mathrm{l}$ of PBS. The injections were made with a fine glass tube attached to a $10 \mu \mathrm{l}$ Hamilton syringe (Hamilton, Reno, NV). Care was taken not to touch the lens during the injection, and animals that showed signs of lens injury were excluded from the study. The needle was slowly removed, and the injection site was sealed with surgical glue (Indermill; Tyco Health Care Canada, Montréal, Québec, Canada). The skin was sutured with 4-0 silk. The vascular integrity of the retina was verified by fundus examination, and animals whose retina showed ischemic damage were excluded from the study. Rats were examined for regeneration after 2 or 4 weeks. To quantify regeneration 2 weeks after optic nerve injury and immediate treatment, 11 animals were treated with the Rho antagonists C3-05 or C3-07, and 10 animals served as buffer and lesion controls. We used five C3-07 treated and 10 control rats in similar experiments in which regeneration was allowed to continue for 4 weeks. We used eight C3-07 treated and five control rats to evaluate regeneration 2 weeks after lesion when application of $\mathrm{C} 3-07$ was delayed until $4 \mathrm{~d}$ after lesion. All animals were given a dose of $0.015 \mathrm{mg} / \mathrm{kg}$ buprenorphine as analgesic after surgery. Animals were kept in a controlled environment where they were exposed to a $12 \mathrm{~h}$ light/dark cycle and had ad libitum access to food and water. All animal procedures followed guidelines from Canadian Council of Animal Care.

Anterograde labeling, immunohistochemistry, and quantification of axon growth. Regenerating axons in the optic nerve were identified by anterograde labeling. Animals received an intravitreal injection of $5 \mu \mathrm{l}$ of $1 \%$ cholera toxin $\beta$ subunit (CT $\beta$ ) (Sigma) $24 \mathrm{~h}$ before they were killed. Animals were deeply anesthetized with a $7 \%$ chloral hydrate overdose, followed immediately by intracardial perfusion with saline and then $4 \%$ paraformaldehyde (PFA) in $0.1 \mathrm{~m}$ phosphate buffer (PB), pH 7.2. The eyes were dissected in cold PBS, and the optic nerve was separated from the eye behind the globe. The nerves were cryoprotected overnight in $30 \%$ sucrose in PBS, embedded in Tissue-Tek (VWR Scientific Products, Montréal, Québec, Canada), and frozen in 2-methylbutane in a liquid nitrogen bath. Longitudinal cryostat sections of optic nerves $(14 \mu \mathrm{m})$ were mounted on Superfrost Plus slides (Fisher Scientific, Montréal, Québec, Canada) and stored at $-80^{\circ} \mathrm{C}$.

To detect CT $\beta$ in RGC axons, slides were postfixed in $4 \%$ PFA in $0.1 \mathrm{M}$ $\mathrm{PB}$ and blocked for $1 \mathrm{~h}$ with 5\% normal rabbit serum, 3\% bovine serum albumine, $0.2 \%$ Triton X-100, and $1 \mathrm{~mm}$ sodium azide. Slides were then incubated overnight with a goat choleragenoid antibody (1:4000) from List Biological Laboratories (Cedarlanes Laboratories, Hornby, Ontario, 
A

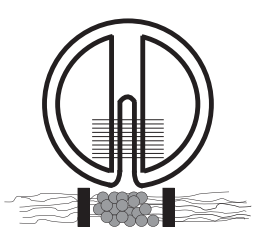

DAx CB/PAx DAx
B

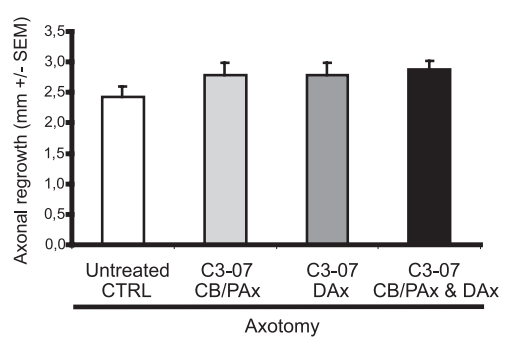

C

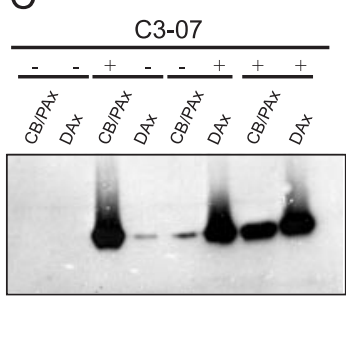

Figure 1. (3-07 and axonal regrowth in vitro after axotomy. $A$, Diagram of compartmented culture showing the Teflon divider and an enlargement of the neurons on a single track among the 16-20 tracks in an individual culture. Compartmented cultures isolate cell bodies and proximal axons (CB/PAx) and distal axons (DAx) of neurons in isolated fluidic compartments. $B, A x o n a l$ regrowth of axotomized axons after application of $C 3-07$ to cell bodies, distal axons, or both. Data represent the average of three or more experiments, each using triplicate cultures. C, Location of (3- $073 \mathrm{~d}$ after application to the cell bodies, distal axons, or both. Four experiments on a Western blot are shown (dashed line), with + and - indicating where (3-07 was or was not applied. Each lane shows pooled lysates from three chambers probed with a polyclonal anti-C3 antibody.

Canada), followed by a $1 \mathrm{~h}$ incubation with an anti-goat biotinylated antibody (1:200) (Vector Laboratories, Burlington, Ontario, Canada), and a $1 \mathrm{~h}$ incubation with streptavidin conjugated to dichlorotriazinyl amino fluorescein $(1: 400)$ from Jackson ImmunoResearch (Cedarlanes Laboratories, Hornby, Ontario, Canada).

Four to 10 sections per animal were examined by epifluorescence microscopy to detect CT $\beta$-labeled axons and were photographed. The lesion site was identified using both the CT $\beta$ staining and dark-field microscopy. Regeneration was measured by counting the number of CT $\beta$ positive axons crossing a line parallel to the lesion site at distances of 50 , 100,250 , and $500 \mu \mathrm{m}$. The longest axon was measured for each animal. Statistical significances were established using Student's $t$ test $\left({ }^{* *} p<\right.$ $\left.0.001 ;{ }^{* *} p<0.01 ;{ }^{\star} p<0.05\right)$. Statistical tests were performed using In Stat (Graph Pad, San Diego, CA).
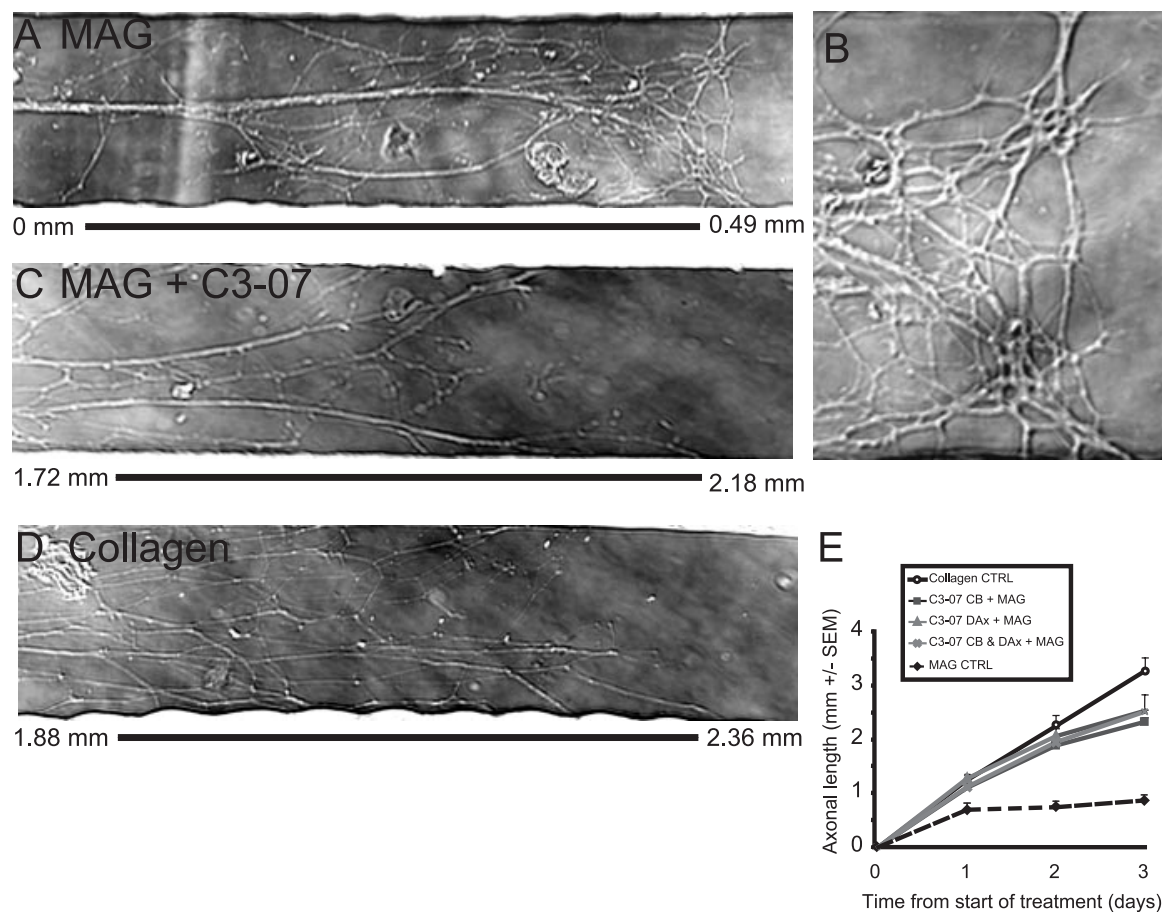

Figure 2. (3-07 promotes axonal growth on MAG substrates, independently of the cellular location of application. $A-D$, Micrographs of the most distal region of axons of rat sympathetic neurons plated in Campenot chambers, with the measurement bar to show the distance of axon growth. $A$, Axons on MAG substrates that stop at $0.49 \mathrm{~mm}$. B, Higher magnification of the same micrograph as in $A$, showing distal axons as they contact MAG substrates. C, Axons on MAG substrates treated with C3- 07 grow $>2 \mathrm{~mm}$. D, Axons plated on collagen substrates grow $>2 \mathrm{~mm}$. E, Measurement of the average axonal length. Data represent the average of four or more experiments performed in triplicate. (Pierce).
Western blots of retina and optic nerve homogenates. Microlesion of the left optic nerve was performed as described above, and $5 \mu \mathrm{g}$ of C3-07 was injected intravitreally. Animals were killed $3 \mathrm{~d}$ later by a $7 \%$ chloral hydrate overdose, followed by an intracardial perfusion with saline. The retina and first $2 \mathrm{~mm}$ segment of the optic nerve were removed and stored at $-80^{\circ} \mathrm{C}$. Tissues were homogenized in $160 \mu \mathrm{l}$ (retinas) or $20 \mu \mathrm{l}$ (optic nerve segments) of NP-40 lysis buffer [20 mM Tris, pH 8.0, $137.5 \mathrm{~mm} \mathrm{NaCl}$, $10 \%$ glycerol, $1 \% \mathrm{~Np} 40,1 \mu \mathrm{g} / \mathrm{ml}$ leupeptin, 1 $\mu \mathrm{g} / \mathrm{ml}$ aprotinin, $1 \mu \mathrm{g} / \mathrm{ml}$ pepstatin (Roche), 1 mM PMSF]. Lysates were clarified by highspeed centrifugation for $5 \mathrm{~min}$ at $4^{\circ} \mathrm{C}$. Supernatants were removed and centrifuged at high speed for $15 \mathrm{~min}$. Samples $(20 \mu \mathrm{l})$ were separated on a $12 \%$ acrylamide gel and transferred to nitrocellulose. Membranes were blocked in $5 \%$ powdered milk and incubated overnight at $4^{\circ} \mathrm{C}$ with a polyclonal C3 antibody $(1: 25,000)$ The signals were revealed by HRP-based chemiluminescent reaction

Retrograde labeling and quantitation of RGC survival. RGCs were retrogradely labeled from the superior colliculus with Fluorogold (Fluorochrome, Denver, CO). The right midbrain was exposed, the pia matter overlying the superior colliculus was removed, and small pieces of gelfoam soaked in a $2 \%$ solution of Fluorogold in $0.9 \%$ saline containing $10 \%$ dimethyl sulfoxyde (Sigma) were applied to the surface of the superior colliculus. One week later, the left optic nerve was transected $1 \mathrm{~mm}$ from the globe, and the left eye was injected intravitreally with $1 \mu \mathrm{g}$ or 10 $\mu \mathrm{g}$ of C3-07 in $5 \mu \mathrm{l}$ of vehicle or with vehicle only ( $5 \mathrm{~mm}$ HEPES). Whole mounts of retinas were prepared from perfused animals at 7 or $14 \mathrm{~d}$ after optic nerve injury. Labeled RGCs were counted under fluorescence microscopy in two regions, located 1 and $2 \mathrm{~mm}$ from the optic disc, of two quadrants of the retina, and average density of RGCs was evaluated in RGCs $/ \mathrm{mm}^{2}$.

Radiolabeling and intracranial optic nerve crush. To radiolabel RGC proteins in the left eye, intraocular injection of $250 \mu \mathrm{Ci}$ of ${ }^{35} \mathrm{~S}$ methionine (ICN Canada, Montréal, Québec, Canada) in $5 \mu \mathrm{l}$ of saline was performed on female Sprague Dawley rats (180-200 g) under gas anesthesia with $2.5-3 \%$ isoflurane in oxygen. Intracranial crush was performed on the left optic nerve by aspirating a portion of the left frontal lobe. The RGC axons were severed just in front of the chiasma, $\sim 9 \mathrm{~mm}$ from the optic disc, by crushing the optic nerve two to three times for 5-10 s with fine forceps. Treated animals were injected in the left eye with $1 \mu \mathrm{g}$ of C3-07 and diluted in $5 \mu$ l of PBS, whereas control animals were injected with $5 \mu$ l of PBS. In groups subjected to a crush and treatment, the injection was performed immediately after the crush. Intravitreal injections, skin suturing, verification of vascular integrity, and administration of postsurgery analgesic were performed as described above. Animals were injected subcutaneously with $10 \mathrm{ml}$ of saline after optic nerve crush surgery.

Animals were separated in five groups for axonal transport experiments. Two groups were killed $6 \mathrm{~d}(n=3)$ or $14 \mathrm{~d}(n=3)$ after labeling, without nerve crush or treatment. The remaining groups were all killed $14 \mathrm{~d}$ after labeling, following an intracranial crush performed $6 \mathrm{~d}$ after labeling. One group received a C3-07 in- 
jection immediately after the lesion $(n=4)$, another received a PBS injection $(n=3)$, and the last group had no injection $(n=4)$.

In another experiment, animals did not have an optic nerve crush but received a C3-07 injection $6 \mathrm{~d}$ after labeling and were killed $8 \mathrm{~d}$ later $(n=3)$.

Evaluation of slow axonal transport. Six or $14 \mathrm{~d}$ after radiolabeling, animals used for slow axonal transport experiments were killed by a $7 \%$ chloral hydrate overdose, followed immediately by intracardial perfusion with saline. The left optic nerve was removed, cut into $2 \mathrm{~mm}$ segments, and stored at $-80^{\circ} \mathrm{C}$. Each $2 \mathrm{~mm}$ segment of optic nerve was homogenized in $60 \mu \mathrm{l}$ of SDS-PAGE sample buffer using a motorized Teflon-in-glass homogenizer. The samples were clarified by high-speed microcentrifugation for $5 \mathrm{~min}$, and $40 \mu \mathrm{l}$ of supernatant per sample was boiled for $3 \mathrm{~min}$ and clarified again by high-speed microcentrifugation for $15 \mathrm{~min}$. Samples were then loaded on $7.5 \%$ acrylamide gels for electrophoretic separation. The gels were stained with Coomassie Blue, destained in $10 \%$ acetic acid, impregnated with Amplify (Amersham Biosciences, Montréal, Québec, Canada), dried, and exposed to preflashed Hyperfilm MP (Amersham Biosciences) for periods varying from 1 to $6 \mathrm{~d}$. Slow axonal transport was assessed by following the advance of the 150 $\mathrm{kDa}$ middle neurofilament subunit (NF-M) labeling front across the five optic nerve segments. The position of the front was determined as the segment preceding the one in which the protein density dropped to $10 \%$ of its highest value for that animal. The expression level of NF-M is $85 \%$ of controls 2 weeks after an intracranial crush of the optic nerve (McKerracher et al., 1993). NF-M lanes of an autoradiograph were scanned for densitometry using an Epson perfection 1200U scanner, transferred to Adobe Photoshop 6.0 (Adobe Systems, San Jose, CA), and the images were analyzed with the densitometry IQ MAC 1.2 software (Molecular Dynamics, Sunnyvale, CA).

\section{Results}

Localized application of C3-07

after axotomy

To determine any effects of C3-07 on normal axon growth, we applied cellpermeable Rho antagonist C3-07 to cell bodies or distal axons in sympathetic neurons plated in compartmented cultures (Fig. $1 A$ ). The cultures were maintained for $5-7 \mathrm{~d}$, at which time axons in the distal chambers were axotomized. Immediately after axotomy, media with C3-07 $(2.5 \mu \mathrm{g} / \mathrm{ml})$ was added to selected compartments, and axonal regrowth was measured 3 d later. C3-07 did not significantly increase the rate that axons extended along the tracks after axotomy, but there was $\sim 15 \%$ enhancement of growth rate, independently of the site of application (Fig. 1B). Treatment of both cell bodies and axons did not further increase the response to the treatment.

After axonal regrowth was measured in the above experiment, lysates from cell body compartments and distal axon compartments were prepared, and the proteins were separated by electrophoresis. Western blot analysis revealed that the preponderance of C3-07 localized to the cellular regions within the compartments in which it was directly applied, although a relatively small
B

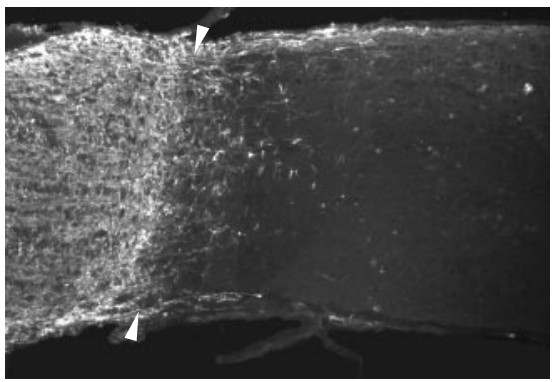

C3-07
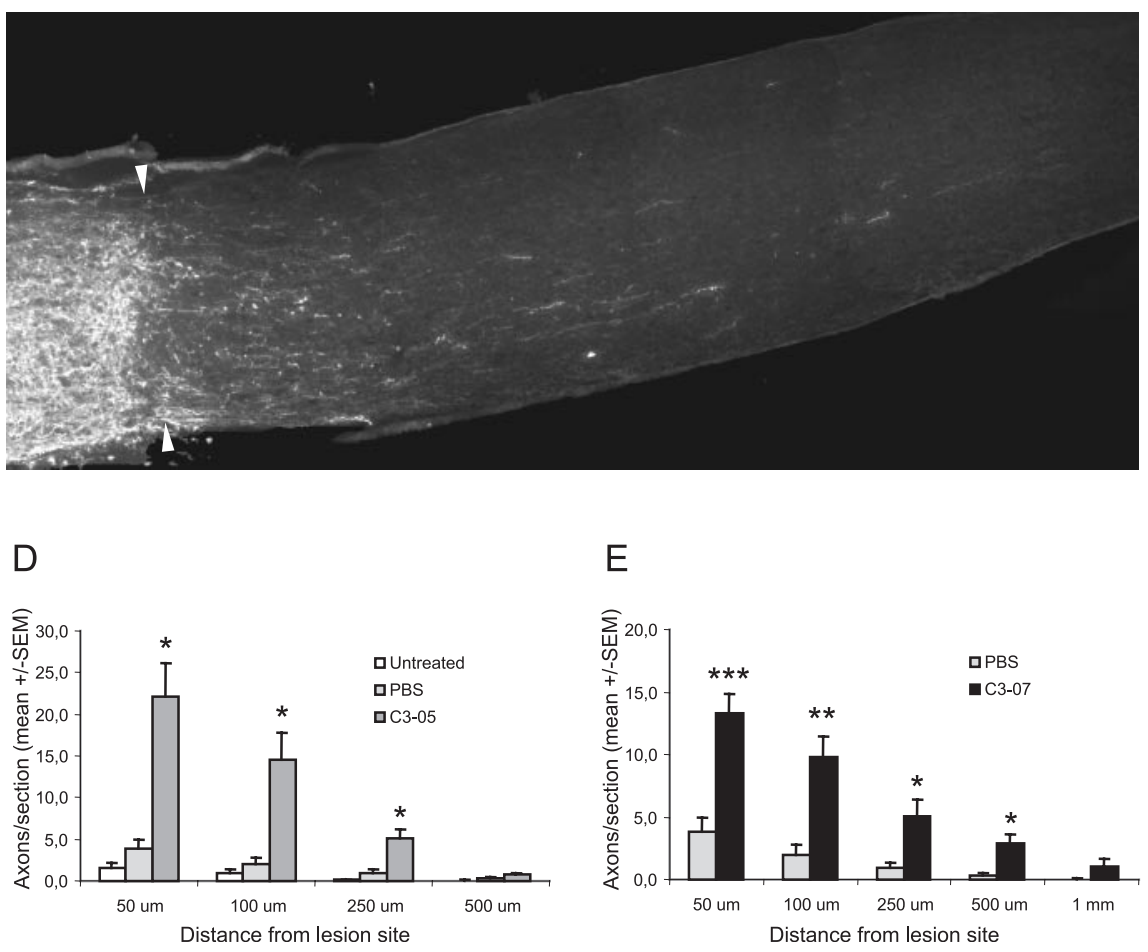

Figure 3. Immediate treatment with intravitreal injection of $\mathrm{C3}-05$ or $\mathrm{C3}-07$ stimulates regeneration in the optic nerve after 2 weeks. $A-C$, Photographs of optic nerve sections immunostained with a $C \mathrm{~T} \beta$ antibody to reveal axons regenerating distally to

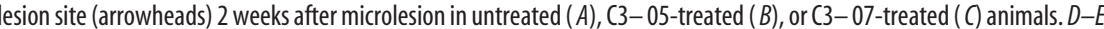
Quantification of regeneration 2 weeks after microlesion in $(3-05$ (D)- and C3- 07 (E)-treated animals, compared with controls. Scale bar: (in $A) A-C, 100 \mu \mathrm{m} .{ }^{* * *} p<0.001 ;{ }^{* *} p<0.01 ;{ }^{*} p<0.05$; Student's $t$ test.

amount of C3-07 applied to cell bodies traveled into distal axons and vice versa (Fig. $1 C$ ).

\section{Localized application of C3-07 promotes axonal growth on MAG substrate}

Inactivation of Rho stimulates neurite outgrowth on inhibitory substrates when neurons in culture are exposed to Rho antagonists (Lehmann et al., 1999; Dergham et al., 2002; Winton et al., 2002; Monnier et al., 2003). We determined whether C3-07 application to either the cell body compartment or the distal axon compartments was sufficient to overcome growth inhibition by MAG. The MAG substrate was added to the side compartments of collagen-coated dishes, in areas that would correspond to the side chambers of the compartmented cultures. Sympathetic neurons were plated in the center compartment, and after $1 \mathrm{~d}$ in culture, when axons were just entering the side compartments, C3-07 $(2.5 \mu \mathrm{g} / \mathrm{ml})$ was added to the culture media of the cell body compartment, both distal axon compartments, or all three 
compartments. Without C3-07 treatment, most axons contacting the MAG substrate collapsed, inhibiting neurite outgrowth (Fig. 2A,B). With C3-07 treatment, however, axonal growth on MAG (Fig. 2C) was similar to growth of control axons on collagen (Fig. 2D). Addition of C3-07 to either the cell body compartment or the distal axon compartments was sufficient to induce growth on MAG, but axonal length was not further increased when all compartments were exposed to C3-07 (Fig. 2E). After $3 \mathrm{~d}$, treatment of the cell body compartment resulted in an average growth of $2.3 \mathrm{~mm}$, compared with $2.5 \mathrm{~mm}$ for treatment of the distal axon compartments or for treatment of all compartments. At the same time point, the axons of control neurons plated on collagen without MAG had grown $~ 25 \%$ farther than the axons of C3-07-treated neurons growing on the MAG substrate (Fig. $2 E$ ). Most of this difference occurred between days 2 and 3 of growth. Because the $\mathrm{C} 3-07$ had been replenished on day 2 , this was not likely produced by a reduction of the effect of C3-07. Rather, it seems likely that the growth-promoting effect of C3-07 does not last indefinitely. Therefore, we conclude that C3-07 promotes axonal growth on inhibitory MAG substrate, regardless of the site of application.

\section{Intravitreal injection of C3-05 or C3-07 stimulates regeneration in the optic nerve}

Previous results demonstrated that in the adult rat, an application of $\mathrm{C} 3$ at the site of an optic nerve lesion promotes axon regeneration (Lehmann et al., 1999). To test whether treatment of the RGC cell bodies promoted regeneration in vivo, we injected Rho antagonists into the vitreous immediately after microlesion of the optic nerve $1 \mathrm{~mm}$ behind the optic disc. In the first experiments, we used C3-05 $(n=4)$, an affinity-purified cell-permeable variant of C3, until a more highly purified version, C3-07 $(n=7)$, became available. Both have the same enzymatic activity and transport sequence. Control animals received a PBS injection $(n=5)$ or microlesion alone $(n=5)$. Axon regeneration in the optic nerve was evaluated $14 \mathrm{~d}$ later, after an injection of the anterograde tracer CT $\beta$.

Two weeks after microlesion, virtually no CT $\beta$-positive axons were detectable in control animals (Fig. $3 A$ ), whereas a large number of axons were visible past the lesion site in $\mathrm{C} 3-05$ (Fig. $3 B$ )- and C3-07-treated rats (Fig. 3C). The microcrush injury model provides a clearly defined lesion site with little or no cavitation (Selles-Navarro et al., 2001), and the lesion site was identified by dark-field microscopy and/or CT $\beta$ staining. The number of axons present at different distances past the lesion site was then counted. Animals treated with C3-05 (Fig. 3D) or C3-07 (Fig. $3 E$ ) had a significantly higher number of regenerating axons per section than controls, at distances of 50, 100, and $250 \mu \mathrm{m}$ from the lesion site. Regeneration in animals injected with C3-07 was similar to that of C3-05-treated animals, but we observed a greater number of longer axons in some animals treated with the more highly purified C3-07 (Fig. 3C).

C3-05 was also used to evaluate regeneration 4 weeks after microlesion. At that time point, we still observed significantly more axons growing past the lesion site in the C3-05-treated group $(n=5)$ than in the control groups (PBS, $n=5$; microlesion alone, $n=5$ ) at distances of 50, 100, and $250 \mu \mathrm{m}$ (Fig. 4).

These results indicate that application of Rho antagonists C305/07 to RGC cell bodies can promote optic nerve regeneration after microlesion. To examine whether treatment had a sustained effect on axon growth, we compared the average length of the longest axon in treated optic nerves 2 and 4 weeks after axotomy. No significant differences in axon length were detected at 4 weeks

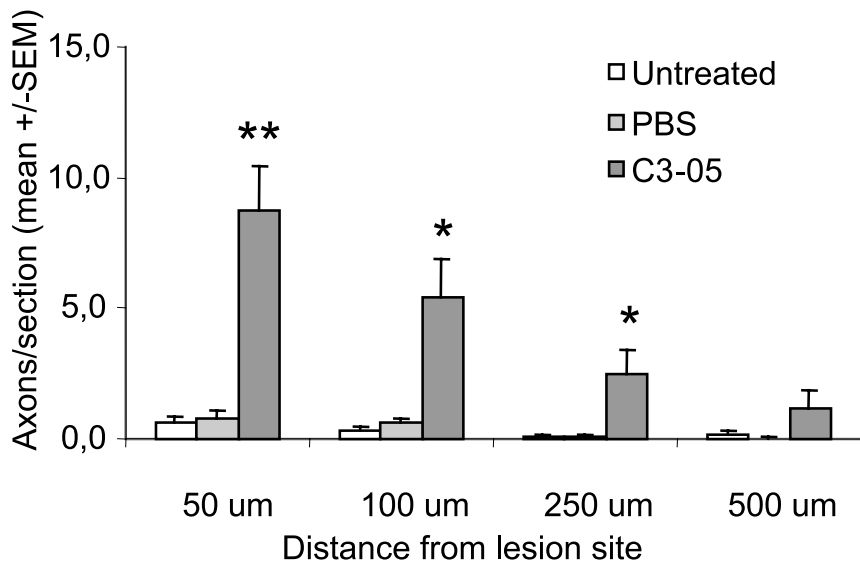

Figure 4. Immediate treatment with intravitreal injection of (3-05 stimulates regeneration in the optic nerve after 4 weeks. Quantification of regeneration 4 weeks after microlesion in C3-05-treated animals compared with controls. ${ }^{* *} p<0.01$; ${ }^{*} p<0.05$; Student's $t$ test.

compared with 2 weeks (data not shown), suggesting that a single treatment does not result in sustained long-term growth.

To examine the localization of C3-07 after injection in the eye, we injected $5 \mu \mathrm{g}$ of C3-07 in the eye after microlesion of the optic nerve. We prepared retina and optic nerve homogenates for Western blots $3 \mathrm{~d}$ later and probed them with an anti-C3 antibody. The specific C3-07 band was compared with recombinant C3-07 protein run in a separate lane (data not shown). We observed full-length C3-07 in optic nerve lysates when C3-07 was injected in the eye (supplemental Fig. 1, available at www.jneurosci.org as supplemental material), in agreement with in vitro studies with compartmented cultures.

\section{Delayed treatment with C3-07 stimulates regeneration through the lesion scar}

By $24 \mathrm{~h}$ after microlesion, a chondroitin sulfate proteoglycan (CSPG)-positive scar is well formed (Selles-Navarro et al., 2001). To determine whether a delayed treatment with C3-07 stimulated regeneration of RGCs through the lesion scar, we injected C3-07 $(n=8)$ in the vitreous $4 \mathrm{~d}$ after microlesion of the optic nerve and examined regeneration $10 \mathrm{~d}$ later. Control animals were injected with PBS $(n=5)$. A large number of CT $\beta$-positive axons could be seen past the lesion site in treated animals, whereas very few were observed in PBS controls (Fig. 5A). Animals treated with C3-07 had a significantly higher number of regenerating axons per section than controls, at distances of 50, 100, 250, and $500 \mu \mathrm{m}$ from the lesion site (Fig. 5B). A comparison of the number of axons per section showed similar numbers of regenerating axons in animals treated with an immediate (Fig. $3 D$ ) or delayed (Fig. $5 B$ ) injection of C3-07. The average longest axon was significantly longer in animals receiving either an immediate or a delayed C3-07 treatment than in PBS controls (Fig. $5 C$ ). These results demonstrate the existence of a therapeutic window for a Rho antagonist treatment after optic nerve injury and indicate that inactivation of Rho allows RGC axons to grow across the lesion scar.

\section{Intravitreal injection of C3-07 increases RGC survival}

We reported previously that inactivation of Rho prevented apoptotic cell death after spinal cord injury (Dubreuil et al., 2003). After injury of the optic nerve, approximately one-half of the RGCs die by apoptosis by 1 week. To determine whether a single intravitreal injection of C3-07 protected RGC from cell death, we 
examined RGC survival in retinal whole mounts. RGCs were retrogradely labeled with Fluorogold 1 week before optic nerve axotomy, and surviving RGCs were counted 7 or $14 \mathrm{~d}$ later in animals treated with C3-07 ( $n=7$ at $7 \mathrm{~d} ; n=5$ at $14 \mathrm{~d}$ ) or vehicle control $(n=3$ at $7 \mathrm{~d} ; n=4$ at $14 \mathrm{~d})$. Treatment with C3-07 completely rescued RGCs 1 week after axotomy, compared with $40 \%$ survival in vehicleinjected animals (Fig. 6). RGC survival after a single injection was not sustained, and RGC numbers decreased after 1 week. However, at $14 \mathrm{~d}$, cell survival was still significantly better with C3-07 treatment, with more than twice the number of RGCs in treated animals compared with controls.

\section{Slow axonal transport after \\ C3-07 treatment}

Axonal transport in normal and injured optic nerve of adult rat has been well described (McQuarrie et al., 1986, 1989; McKerracher et al., 1990) and is detected by examining the movement of ${ }^{35} \mathrm{~S}$ methionine-labeled proteins along $2 \mathrm{~mm}$ optic nerve segments. In uninjured optic nerve, the rate of slow axonal transport of neurofilament, as detected by the $150 \mathrm{kDa}$ middle neurofilament subunit (NF-M), is $\sim 0.5 \mathrm{~mm} / \mathrm{d}$ (McQuarrie et al., 1986), and the transport rate decreases significantly when the optic nerve is crushed intracranially near the optic chiasma (McKerracher et al., 1990). To determine whether C3-07 had an impact on slow axonal transport, the optic nerve was crushed $6 \mathrm{~d}$ after labeling, a time when tubulin and neurofilament proteins enter the optic nerve (Fig. 7A). Control animals received no injection or were injected with PBS, and treated animals received an intraocular injection of C3-07 immediately after the crush. Optic nerves were removed $8 \mathrm{~d}$ after crush, a total of $14 \mathrm{~d}$ after labeling, and were cut into five segments of $2 \mathrm{~mm}$ each (supplemental Fig. 2, available at www.jneurosci.org as supplemental material).

The NF-M front in uninjured control animals reached the second segment $6 \mathrm{~d}$ after labeling (Fig. $7 A$ ) and progressed to the fifth segment by $14 \mathrm{~d}$ after labeling (Fig. $7 B$ ). In untreated animals whose nerve was crushed $6 \mathrm{~d}$ after labeling, the NF-M front reached the third segment $14 \mathrm{~d}$ after labeling (Fig. $7 C, D$ ). This distance is similar to that observed in animals who were killed $6 \mathrm{~d}$ after labeling (Fig. 7A), showing a dramatic decrease in slow axonal transport after optic nerve crush. When C3-07 was injected in the vitreous immediately after the optic nerve crush (Fig. 7E), the NF-M front traveled no further than it did in control axotomized animals with no injection (Fig. 7C) or PBS injection (Fig. 7D). Therefore, C3-07 did not increase slow axonal transport after injury. We also tested whether $\mathrm{C} 3-07$ affected slow axonal transport in uninjured nerve. The distance traveled by the NF-M front in uninjured animals after C3-07 injection at day 6 after labeling was not changed at $14 \mathrm{~d}$ (data not shown).

\section{Discussion}

These findings show that C3-based Rho antagonists have a growth-promoting effect on distal axons even when applied to

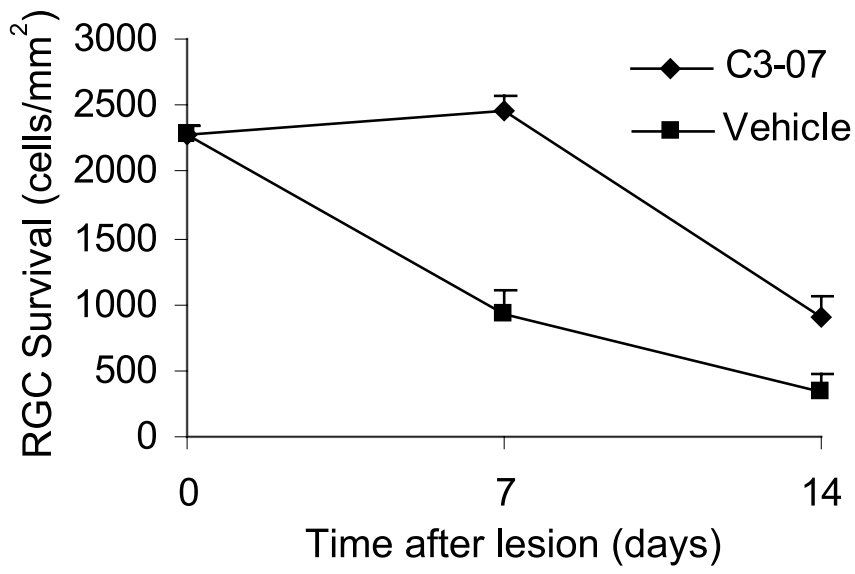

Figure 6. (3- 07 promotes survival of axotomized RGCs. RGCs were retrogradely labeled 1 week before optic nerve injury. (3-07 or vehicle was injected into the vitreous after optic nerve transection, and retrogradely labeled $\mathrm{RGCs}$ were counted in retinal whole mounts prepared 7 or $14 \mathrm{~d}$ after axotomy.

neuronal cell bodies. Our in vitro experiments with compartmented cultures indicate that $\mathrm{C} 3-07$ promotes axonal growth on inhibitory substrates when applied to either cell bodies or distal axons. Previous treatments tested in compartmented cultures, such as NGF (Campenot, 1994) or glial cell-conditioned medium (Hayashi et al., 2004), promoted axonal growth when applied in distal axon compartments but not when applied in the cell body chamber. In vivo, treatment of cell bodies with an intraocular application of C3-05 or C3-07 promoted axon regeneration similar to that obtained with an application of C3 to injured optic nerve (Lehmann et al., 1999). Therefore, both in vitro and in vivo 
A

\begin{abstract}
Day 0: ${ }^{35}$ S-methionine
Day 6: optic nerve removal
\end{abstract}

Day 14:

$\begin{array}{lllll}1 & 2 & 3 & 4 & 5\end{array}$

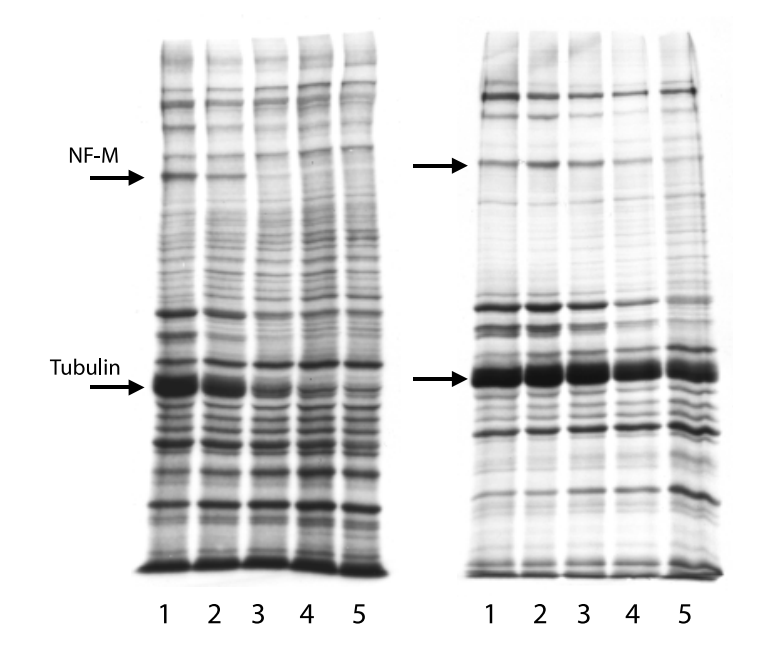

B

${ }^{35}$ S-methionine

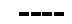

optic nerve removal
C

${ }^{35}$ S-methionine

crush

optic nerve removal

D

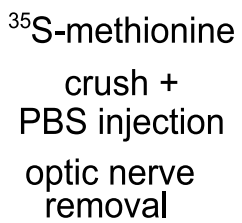

E
${ }^{35} \mathrm{~S}$-methionine crush + C3-07 injection optic nerve removal
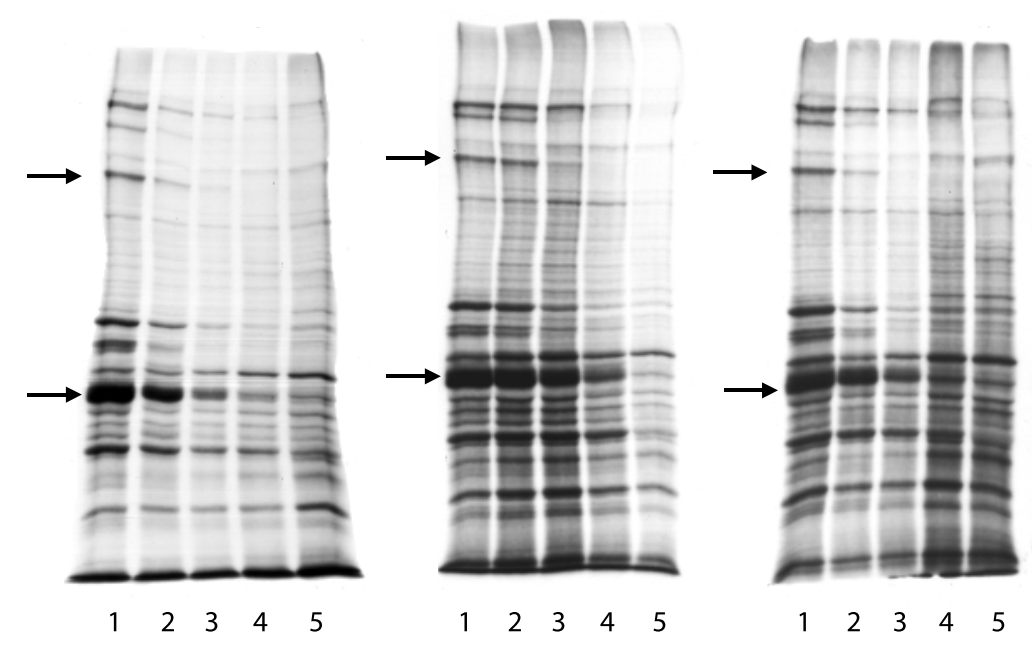

$\begin{array}{lllll}1 & 2 & 3 & 4 & 5\end{array}$

\section{Segments}

Figure 7. C3-07 does not accelerate slow axonal transport after intracranial optic nerve crush. Detection of slowly transported tubulin and NF-M (arrows) after ${ }^{35} S$-methionine labeling shows the labeling front as these proteins are transported into the optic nerve with time. $A, B$, Transport in normal optic nerve detected at day $6(A)$ and day $14(B)$. $C-E$, Axonal transport after optic nerve injury alone $(C)$, injury and PBS injection $(D)$, or injury and $(3-07$ injection $(E)$.

experiments suggest that the site of application of Rho antagonists is not determinant for promoting axonal growth and regeneration in the presence of growth inhibitors.

We are the first to directly compare the effect of the application of a Rho antagonist to cell bodies versus injured axons. Other studies show growth-promoting factors are effective in stimulating axonal regeneration when applied to the eye, such as factors secreted in the retina after lens injury or intravitreal implantation of peripheral nerve graft (So and Aguayo, 1985; Leon et al., 2000). Intravitreal grafting of acellular peripheral nerve has a small regenerative effect on RGCs (Berry et al., 1996), whereas acellular grafts connected to the cut end of the optic nerve do not (Berry et al., 1988; Hall and Berry, 1989). In contrast, inhibitors of Nogo have only been tested after application to the injured optic nerve (Weibel et al., 1994; Cui et al., 2004).

The similarity of results on axonal growth and regeneration when C3-07 is applied at the cell bodies or injured axons can be explained, at least in part, by diffusion or active transport of C3-07 between cell body and axon. C3-07 initially applied to the cell body was later detected in untreated axons in our in vitro and in vivo experiments. Therefore, the effect of Rho antagonists on regeneration could result from known actions on the actin cytoskeleton at the growth cones. C3-07 might prevent growth cone collapse through its known action on blocking inhibitory signaling. The increased survival observed 2 weeks after lesion in C3-07-treated animals might also contribute to the higher level of regeneration, although survival strategies alone are not sufficient to promote regeneration (Mansour-Robaey et al., 1994; Inoue et al., 2002).

Here, we report that treatment with $\mathrm{C} 3-07$ prevented death of
RGCs for at least 1 week, a finding consistent with a recent report on RGCs transfected in vivo with a C3-construct in which increased RGC survival was reported (Fischer et al., 2004b). However, one difference in the two studies is that Fischer et al. (2004b) reported only a partial increase in RGC survival, perhaps explained by transfection efficiency. Possibly, the application of cell-permeable C3-07 in our study affected other cells, such as Muller cells, that might also influence cell survival. It is important to note that the survival rates that we report here are comparable with the best results obtained when the neurotrophic factor BDNF is injected in the vitreous after axotomy (Mansour-Robaey et al., 1994; Peinado-Ramon et al., 1996). BDNF is also able to rescue all RGCs from axotomy at 1 week after intraocular injection, and RGCs begin to die between 7 and $14 \mathrm{~d}$. Similarly, the effect of C3-07 is not sustained after a single application, and RGCs begin to die between 1 and 2 weeks after axotomy.

We have shown previously that CSPG-immunoreactive proteins are expressed at the optic nerve lesion site as early as $24 \mathrm{~h}$ after the injury (Selles-Navarro et al., 2001). The axonal regeneration observed when application of C3-07 was delayed for $4 \mathrm{~d}$ after optic nerve injury demonstrates that RGC can grow past the scar when Rho is inactivated. This observation supports studies showing that Rho inactivation with $\mathrm{C} 3-07$ promotes axon growth through scars formed in vitro with meningeal cells that express CSPGs (Shearer et al., 2003).

Our results clearly show that inactivating Rho with C3-07 applied to the cell bodies promotes regeneration of RGC axons. However, regenerating axons did not grow for long distances after crossing the lesion site, a result consistent with findings from most studies on regeneration in the rat optic nerve (Leh- 
mann et al., 1999; Leon et al., 2000; Ellezam et al., 2003; Sapieha et al., 2003; Fischer et al., 2004a). Treatments such as vaccination with a spinal cord homogenate or application of $\mathrm{C} 3$ to the lesion site can induce a much longer regeneration in the spinal cord (Huang et al., 1999; Dergham et al., 2002) than in the optic nerve (Lehmann et al., 1999; Ellezam et al., 2003), a finding not well understood. The number of regenerating axons is another important determinant when examining regeneration. Although numbers of regenerating RGCs are significant after Rho inactivation, the number of RGCs that regenerate are small, even though C3-07 has a survival-promoting effect. We estimate that only $0.5 \%$ of RGC axons extend past the lesion site. This small number could be explained in part by the finding that $<1 \%$ of postnatal RGCs retain rapid axonal elongation capabilities (Goldberg et al., 2002a). In contrast, many more RGCs can grow in the permissive environment of a peripheral nerve (PN) graft (Villegas-Perez et al., 1988; Cui et al., 2003). It was shown recently that the combination of Rho inactivation with lens injury could increase dramatically the success of regeneration, compared with $\mathrm{C} 3$ alone, even though not all RGCs were transfected with the $\mathrm{C} 3$ construct (Fischer et al., 2004b). It has been suggested that combination therapies offer the best hope for robust and substantial regeneration, a suggestion supported by other recent investigations of RGC regeneration. Combining CNTF treatment with Nogoneutralizing antibody IN-1 (Cui et al., 2004) was more effective than either strategy alone. Dominant-negative Nogo receptor expressed in RGCs in vivo does not promote regeneration, but when combined with lens injury, there was a robust regeneration better than lens injury alone (Fischer et al., 2004a). RGCs lose their trophic responsiveness after axotomy (Shen et al., 1999), and RGCs require "priming," such as by treatment with cAMP, to help increase their responsiveness to neurotrophic factors (Goldberg et al., 2002b). Together, current studies suggest that combining Rho inactivation with treatments that prime mature RGCs into a growth mode enhances the number of RGCs regenerating over long distances into an inhibitory environment.

Our experiments confirmed a previous report that slow axonal transport is almost completely stopped after an intracranial crush of the optic nerve (McKerracher et al., 1990). Typically, RGCs do not regenerate with intracranial injury, even when a PN graft is provided (Richardson et al., 1982; You et al., 2000). However, combining intraocular growth factors with a PN graft promotes RGC regeneration after distal axotomy (Cui et al., 1999). Slow axonal transport is critical to regeneration because it supplies cytoskeletal proteins that are required to support axon elongation. To test the effect of Rho inactivation on slow axonal transport, we axotomized optic nerves near the chiasma, which is almost $1 \mathrm{~cm}$ farther than the site of axotomy used for our regeneration experiments. This change was necessary to provide a sufficient length of optic nerve for the transport experiments, but it should be noted that there are differences in RGC survival and regenerative ability with intraorbital and intracranial axotomy (Villegas-Perez et al., 1993; You et al., 2000). C3-07 did not prevent the decrease in slow axonal transport after intracranial axotomy, suggesting that, under these conditions, C3-07 does not have a priming effect, even though it can promote RGC survival.

\section{References}

Berry M, Hall S, Follows R, Rees L, Gregson N, Sievers J (1988) Response of axons and glia at the site of anastomosis between the optic nerve and cellular or acellular sciatic nerve grafts. J Neurocytol 17:727-744.

Berry M, Carlile J, Hunter A (1996) Peripheral nerve explants grafted into the vitreous body of the eye promote the regeneration of retinal ganglion cell axons severed in the optic nerve. J Neurocytol 25:147-170.

Campenot RB (1977) Local control of neurite development by nerve growth factor. Proc Natl Acad Sci USA 74:4516-4519.

Campenot RB (1979) Independent control of the local environment of somas and neurites. Methods Enzymol 58:302-307.

Campenot RB (1994) NGF and the local control of nerve terminal growth. J Neurobiol 25:599-611.

Campenot RB, Martin G (2001) Construction and use of compartmented cultures for studies of cell biology of neurons. In: Protocols for neural cell culture (Federoff A, Richardson A, eds), pp 49-57. Totowa, NJ: Humana.

Cui Q, Lu Q, So KF, Yip HK (1999) CNTF, not other trophic factors, promotes axonal regeneration of axotomized retinal ganglion cells in adult hamsters. Invest Ophthalmol Vis Sci 40:760-766.

Cui Q, Yip HK, Zhao RC, So KF, Harvey AR (2003) Intraocular elevation of cyclic AMP potentiates ciliary neurotrophic factor-induced regeneration of adult rat retinal ganglion cell axons. Mol Cell Neurosci 22:49-61.

Cui Q, Cho KS, So KF, Yip HK (2004) Synergistic effect of Nogoneutralizing antibody IN-1 and ciliary neurotrophic factor on axonal regeneration in adult rodent visual systems. J Neurotrauma 21:617-625.

David S, Lacroix S (2003) Molecular approaches to spinal cord repair. Annu Rev Neurosci 26:411-440.

Dergham P, Ellezam B, Essagian C, Avedissian H, Lubell WD, McKerracher L (2002) Rho signaling pathway targeted to promote spinal cord repair. J Neurosci 22:6570-6577.

Dubreuil CI, Winton MJ, McKerracher L (2003) Rho activation patterns after spinal cord injury and the role of activated Rho in apoptosis in the central nervous system. J Cell Biol 162:233-243.

Ellezam B, Bertrand J, Dergham P, McKerracher L (2003) Vaccination stimulates retinal ganglion cell regeneration in the adult optic nerve. Neurobiol Dis 12:1-10.

Fischer D, He Z, Benowitz LI (2004a) Counteracting the Nogo receptor enhances optic nerve regeneration if retinal ganglion cells are in an active growth state. J Neurosci 24:1646-1651.

Fischer D, Petkova V, Thanos S, Benowitz LI (2004b) Switching mature retinal ganglion cells to a robust growth state in vivo: gene expression and synergy with RhoA inactivation. J Neurosci 24:8726-8740.

Goldberg JL, Klassen MP, Hua Y, Barres BA (2002a) Amacrine-signaled loss of intrinsic axon growth ability by retinal ganglion cells. Science 296:1860-1864.

Goldberg JL, Espinosa JS, Xu Y, Davidson N, Kovacs GT, Barres BA (2002b) Retinal ganglion cells do not extend axons by default: promotion by neurotrophic signaling and electrical activity. Neuron 33:689-702.

Hall S, Berry M (1989) Electron microscopic study of the interaction of axons and glia at the site of anastomosis between the optic nerve and cellular or acellular sciatic nerve grafts. J Neurocytol 18:171-184.

Han S, Arvai AS, Clancy SB, Tainer JA (2001) Crystal structure and novel recognition motif of rho ADP-ribosylating C3 exoenzyme from Clostridium botulinum: structural insights for recognition specificity and catalysis. J Mol Biol 305:95-107.

Hayashi H, Campenot RB, Vance DE, Vance JE (2004) Glial lipoproteins stimulate axon growth of central nervous system neurons in compartmented cultures. J Biol Chem 279:14009-14015.

Huang DW, McKerracher L, Braun PE, David S (1999) A therapeutic vaccine approach to stimulate axon regeneration in the adult mammalian spinal cord. Neuron 24:639-647.

Inoue T, Hosokawa M, Morigiwa K, Ohashi Y, Fukuda Y (2002) Bcl-2 overexpression does not enhance in vivo axonal regeneration of retinal ganglion cells after peripheral nerve transplantation in adult mice. J Neurosci 22:4468-4477.

Jalink K, van Corven EJ, Hengeveld T, Morii N, Narumiya S, Moolenaar WH (1994) Inhibition of lysophosphatidate- and thrombin-induced neurite retraction and neuronal cell rounding by ADP ribosylation of the small GTP-binding protein Rho. J Cell Biol 126:801-810.

Jin Z, Strittmatter SM (1997) Racl mediates collapsin-1-induced growth cone collapse. J Neurosci 17:6256-6263.

Kimpinski K, Campenot RB, Mearow K (1997) Effects of the neurotrophins nerve growth factor, neurotrophin-3, and brain-derived neurotrophic factor (BDNF) on neurite growth from adult sensory neurons in compartmented cultures. J Neurobiol 33:395-410.

Lehmann M, Fournier A, Selles-Navarro I, Dergham P, Sebok A, Leclerc N, 
Tigyi G, McKerracher L (1999) Inactivation of Rho signaling pathway promotes CNS axon regeneration. J Neurosci 19:7537-7547.

Leon S, Yin Y, Nguyen J, Irwin N, Benowitz LI (2000) Lens injury stimulates axon regeneration in the mature rat optic nerve. J Neurosci 20:4615-4626.

MacInnis BL, Senger DL, Campenot RB (2003) Spatial requirements for TrkA kinase activity in the support of neuronal survival and axon growth in rat sympathetic neurons. Neuropharmacology 45:995-1010.

Mansour-Robaey S, Clarke DB, Wang YC, Bray GM, Aguayo AJ (1994) Effects of ocular injury and administration of brain-derived neurotrophic factor on survival and regrowth of axotomized retinal ganglion cells. Proc Natl Acad Sci USA 91:1632-1636.

McKerracher L, Winton MJ (2002) Nogo on the go. Neuron 36:345-348.

McKerracher L, Vidal-Sanz M, Essagian C, Aguayo AJ (1990) Selective impairment of slow axonal transport after optic nerve injury in adult rats. J Neurosci 10:2834-2841.

McKerracher L, Essagian C, Aguayo AJ (1993) Temporal changes in $\beta$-tubulin and neurofilament mRNA levels after transection of adult rat retinal ganglion cell axons in the optic nerve. J Neurosci 13:2617-2626.

McKerracher L, David S, Jackson DL, Kottis V, Dunn RJ, Braun PE (1994) Identification of myelin-associated glycoprotein as a major myelinderived inhibitor of neurite growth. Neuron 13:805-811.

McQuarrie IG, Brady ST, Lasek RJ (1986) Diversity in the axonal transport of structural proteins: major differences between optic and spinal axons in the rat. J Neurosci 6:1593-1605.

McQuarrie IG, Brady ST, Lasek RJ (1989) Retardation in the slow axonal transport of cytoskeletal elements during maturation and aging. Neurobiol Aging 10:359-365.

Monnier PP, Sierra A, Schwab JM, Henke-Fahle S, Mueller BK (2003) The Rho/ROCK pathway mediates neurite growth-inhibitory activity associated with the chondroitin sulfate proteoglycans of the CNS glial scar. Mol Cell Neurosci 22:319-330.

Monsul NT, Geisendorfer AR, Han PJ, Banik R, Pease ME, Skolasky Jr RL, Hoffman PN (2004) Intraocular injection of dibutyryl cyclic AMP promotes axon regeneration in rat optic nerve. Exp Neurol 186:124-133.

Peinado-Ramon P, Salvador M, Villegas-Perez MP, Vidal-Sanz M (1996) Effects of axotomy and intraocular administration of NT-4, NT-3, and brain-derived neurotrophic factor on the survival of adult rat retinal ganglion cells. A quantitative in vivo study. Invest Ophthalmol Vis Sci 37:489-500.
Richardson PM, Issa VM, Shemie S (1982) Regeneration and retrograde degeneration of axons in the rat optic nerve. J Neurocytol 11:949-966.

Sapieha PS, Peltier M, Rendahl KG, Manning WC, Di Polo A (2003) Fibroblast growth factor-2 gene delivery stimulates axon growth by adult retinal ganglion cells after acute optic nerve injury. Mol Cell Neurosci 24:656-672.

Selles-Navarro I, Ellezam B, Fajardo R, Latour M, McKerracher L (2001) Retinal ganglion cell and nonneuronal cell responses to a microcrush lesion of adult rat optic nerve. Exp Neurol 167:282-289.

Shearer MC, Niclou SP, Brown D, Asher RA, Holtmaat AJ, Levine JM, Verhaagen J, Fawcett JW (2003) The astrocyte/meningeal cell interface is a barrier to neurite outgrowth which can be overcome by manipulation of inhibitory molecules or axonal signalling pathways. Mol Cell Neurosci 24:913-925.

Shen S, Wiemelt AP, McMorris FA, Barres BA (1999) Retinal ganglion cells lose trophic responsiveness after axotomy. Neuron 23:285-295.

So KF, Aguayo AJ (1985) Lengthy regrowth of cut axons from ganglion cells after peripheral nerve transplantation into the retina of adult rats. Brain Res 328:349-354.

Tigyi G, Fischer DJ, Sebok A, Yang C, Dyer DL, Miledi R (1996) Lysophosphatidic acid-induced neurite retraction in PC12 cells: control by phosphoinositide-Ca ${ }^{2+}$ signaling and Rho. J Neurochem 66:537-548.

Villegas-Perez MP, Vidal-Sanz M, Bray GM, Aguayo AJ (1988) Influences of peripheral nerve grafts on the survival and regrowth of axotomized retinal ganglion cells in adult rats. J Neurosci 8:265-280.

Villegas-Perez MP, Vidal-Sanz M, Rasminsky M, Bray GM, Aguayo AJ (1993) Rapid and protracted phases of retinal ganglion cell loss follow axotomy in the optic nerve of adult rats. J Neurobiol 24:23-36.

Weibel D, Cadelli D, Schwab ME (1994) Regeneration of lesioned rat optic nerve fibers is improved after neutralization of myelin-associated neurite growth inhibitors. Brain Res 642:259-266.

Winton MJ, Dubreuil CI, Lasko D, Leclerc N, McKerracher L (2002) Characterization of new cell permeable C3-like proteins that inactivate Rho and stimulate neurite outgrowth on inhibitory substrates. J Biol Chem 277:32820-32829.

Yin Y, Cui Q, Li Y, Irwin N, Fischer D, Harvey AR, Benowitz LI (2003) Macrophage-derived factors stimulate optic nerve regeneration. J Neurosci 23:2284-2293.

You SW, So KF, Yip HK (2000) Axonal regeneration of retinal ganglion cells depending on the distance of axotomy in adult hamsters. Invest Ophthalmol Vis Sci 41:3165-3170. 